\title{
Effect of Work Conflict on Employees Job Satisfaction: The Case of College of Distance Education, University of Cape Coast
}

\author{
Moses Segbenya \\ Fred Peniana \\ Ebenezer Aggrey
}

College Of Distance Education, University Of Cape Coast, Ghana

Doi: 10.19044/esj.2018.v14n7p313 URL:http://dx.doi.org/10.19044/esj.2018.v14n7p313

\begin{abstract}
The purpose of the study was to examine the effects of work life balance on employees' job satisfaction at College of Distance Education, University of Cape Coast, Ghana-Africa. The study adopted the quantitative research approach specifically a correlational design. From populations of 242, a sample of 140 teaching and non teaching staff of the College was drawn across three spectrums of staff using simple random sampling technique. Instrument for data collection was questionnaire which had items measured on a scale of 1 to 4 with 1 representing strongly disagreement while 4 represented strong agreement. It was found that there was high level of conflict between work schedules and other social demands (low rating for work life balance) among staff of the College. Additionally, the level of job satisfaction among CoDE staff was low. It was also found that that there was a negative but moderate and significant relationship between work life conflict and job satisfaction among staff of CoDE. It was therefore recommended that management of CoDE should: introduce leave schedule or a day off for staff in order to have sufficient time to attend to their personal, marital and social life and rest; introduce job rotation to ensure job satisfaction and work life balance and also introduce inter-unit assignment and recreational activities for staff on public holidays.
\end{abstract}

Keywords: Work- Life- Conflict, Job Satisfaction, Distance Education

\section{Acronyms}

CoDE College of Distance Education

$\mathrm{UCC}$ University of Cape Coast

CoDE/UCC College of Distance Education, University of Cape Coast 


\section{Definition of Terms}

Job satisfaction: In this study, job satisfaction means the degree to which employees/workers like their job.

Staff: staff as used in this study means an employee of the college and has been used interchangeably with a worker or employee.

Work: This refers to the schedules and activities carried out by staff of the college in terms of both administrative and teaching within the weekdays at office and weekends at the study centres across the length and breadth of all the regions in Ghana.

Life: life in this study refers to all other activities performed by workers of the college outside their work schedules. Thus, life in this work means, marital and family responsibilities, attending to personal social and religious needs.

Work life conflict: A situation where a worker/employee of the college is unable to attend to all aspect of "life" (social, religious and personal goals) due to his or her work schedules.

Work life balance: a situation where a worker or employee is able to get time to attend to social, religious and personal goals in addition to meeting work schedules /demands

Work life demand: means the dictates and roles that a worker is expected to carry out as his/her work schedule.

\section{Introduction}

The human resource of every organization debatably continues to remain as the most important resource without which all other resources remain inactive. This important strategic resource of every organization is equally a social being with multi-facet and interwoven roles to perform. That means that apart from work, employees equally have other important social demands to address. The ability of the individual worker to effectively attend to the demands of all the constituents of his/her life such as work, marital, social is what is commonly termed as work life balance. Work life balance issues have been found to affect one's identity, well-being and quality of functioning (Cinamon \& Rich, 2010). This means that proper integration or the lack thereof (called work life conflict) between these interconnected roles has direct implication on the performance of the employee and subsequently the institutional or organizational performance.

Work family conflict thus arises when a worker is unable to manage the demands/dictates of his/her job schedules and others such as marital and religious among others. Factors such as shifts, sudden transfer, frequent overtime, and working hour changes have been identified to be very related to work life conflict (Nicole, 2003). Work life conflict/balance has its theoretical underpinning in the role theory and specifically role conflict theory. 
According to Kartz and Karn (1978) and Greenhause and Powel (2010), the role conflict theory suggests that various roles if not managed well can lead to role conflicts for a worker and this role conflict could either be time based conflict, strained based conflict or behaviour based conflict.

Stress has been identified as one of the consequents of conflicts between work and life. subsequently stress has an adverse implications for employees' health. That is chronic stress can alter employees immune system, cause inflammation, higher blood pressure, hypertension and other cardiovascular issues (Kang-Rice, Park, Turner-Henson, \& Downs (2010). Such conditions are inconsistent with a productive and satisfied workforce. A study conducted by Porter \& Ayman, (2010) and Rabia, Sadaf, Azhar and Sadaqat (2011) revealed that one of the most common reasons for employee turnover is stress and leads to negative outcomes such as fatigue, and absenteeism at work.

Rabia, Sadaf, Azhar and Sadaqat (2011) posit that factors that that can minimize employees' work life conflict issues were organizational culture, supervisor support and family-oriented benefits. Based on this other organizations have turned to policies such as flextime, on-site childcare, and other mechanisms to ensure that engaging in one's family does not interfere with work (Jennings \& McDougald, 2007, Haar \& Roche, 2010).

This calls for proper integration between the demand of both work and life/social.Work life balance thus, is directly linked to academic and non academic staff performance and satisfaction. Rabia, Sadaf, Azhar and Sadaqat (2011) examined the length of workweek and analyzed its relationship to faculty dissatisfaction with work overload. The authors found that many professors were dissatisfied due to heavy workload and dissatisfaction increased with long working hours but long hours spent on job also increased research productivity.

Work life balance/conflict integration issues are equally important to the teaching and non teaching staff of both public and private universities in Ghana as well as Ghanaian employees in general. This importance is reflected in the Ghanaian Labour act 2003 (Act, 651) section 42 which states that every worker should be entitled to a rest period of 48 consecutive hours in every seven days of normal work, and total average hours of work for every week should not exceed 40 hours. The roles of academic and non teaching staff of the universities in Ghana especially in the University of Cape Coast has become more complex and demanding than before with the introduction of the distance education programmes in addition to the regular academic programmes. The distance education programme by the University of Cape Coast under the College of Distance Education is run only on weekends since its inception in 1997. This means that staff of the University either worked in 
the main stream (regular system) or the distance department (distance programme only) or both.

In the case of Staff of College of distance education of the University of Cape Coast for example, staff worked in the office from Mondays to Thursdays and travelled to the study centres during the weekends to monitor 12 weeks of face to face tutoring or teaching, 2 weeks of invigilation of continuous assessment test and 4 weeks of invigilation of end of semester examinations. This means that staff of this College (CoDE,UCC) work seven days in a week and that amount to 56 hours a week which contradict the provisions in the Ghana Labour Act, 2003 (Act,651) and ILO convention. Staff equally have other important demanding roles (here in referred to as life roles) such as religious, marital, academic and social roles to play. The ability to blend work and life roles would lead to ensuring work life balance else that would result in work life conflict. This has implication for performance of staff and the ability of the College to deliver on its mandate and satisfy its stakeholders. Thus this study seeks to examine work and life balance among staff of the College of Distance Education (CoDE/UCC) and its effects on job satisfaction among staff.

\section{Research Questions}

Specific research questions set to achieve above objective were:

1. What is the level of work and life balance; and job satisfaction among staff of CoDE, UCC?

2. What relationship and effect exist between work life conflict on employee job satisfaction at CoDE, UCC?

\section{Literature Review}

According to Shobitha and Sudarsan (2014), there are five or more theories that can be used to explain the relationship between work and life of an individual. The first theory known as segmentation model was of the view that work and non-work are two separate domains of life that are lived quite independently and have no influence on each other. However, in contrast, the spillover theory put forward suggested that one sphere can influence the other sphere in either a positive or negative way. Compensation model as the third model also postulates that work and family are two domains of life and what may be lacking in one sphere, in terms of demands or satisfactions may be derived from the other sphere of life. Thus they complement each other.

A fourth model referred to as an instrumental model, proposes that activities of one sphere may facilitate success in the other sphere. For example an instrumental worker may explore ways to maximize earnings by undertaking hectic overtime work lasting several days against a routine job to purchase a home or a car for their family. Lastly, another model referred to as 
conflict model suggests that individuals encountering high levels of demand in all spheres of life and compelled to make difficult choices may end up in experiencing psychological conflicts with significant overload.

Job satisfaction has been emphasized in theory such by Herzberg's two factor theory. Frederick Herzberg theorized that employee satisfaction has two dimensions: "hygiene" and "motivators". Hygiene issues, such as salary and supervision, decrease employees' dissatisfaction with the work environment. Hygiene issues cannot motivate employees but can minimize dissatisfaction, if handled properly. Motivators, such as recognition and achievement, make workers more productive, creative and committed. Motivators, on the other hand, create satisfaction by fulfilling individuals' needs for meaning and personal growth. Once the hygiene areas have been addressed, the motivators will promote job satisfaction and encourage productions (Mullins, 2010).

The two-factor theory has been criticized on grounds that it only recognizes content and recognition as the only sources of employee motivation. Despite this criticism, Herzberg's two-factor theory remains as one of the popular theories for managers, which also have international appeal. Similarly, the current emphasis on self-development, career management and self-managed learning can be seen as having evolved from Herzberg's twofactor theory (Segbenya,Annan-Prah,Enu-Kwesi \& Koomson 2013).

Job satisfaction has long been recognised as an important variable in explaining institutional performance and turnover intentions. Certain factors are responsible for job satisfaction/dissatisfaction; however, the inability of managers to identify these factors has led to poor performance and high rate of turnover (Olorunjuwon, 2008). Riggio (2003) describes job satisfaction as consisting of the feelings and attitudes one has about one's job including all aspects of a particular job, good and bad, positive and negative, which are likely to contribute to the development of feelings of satisfaction or dissatisfaction or turnover intentions. Job satisfaction or dissatisfaction is predicated upon certain organisational factors and does not exist as an abstract phenomenon. These factors revolve around the work itself or the environmental and human aspect of the organisation.

A survey conducted by the Society of Human Resource Management (SHRM) in the United State of America reported in a study by Wan (2007) listed the top five factors in attaining job satisfaction to be compensation/pay, benefits, job security, flexibility to balance life and work issues, and feeling safe in the work environment. Some of these variables in addition to new ones are relevant to CoDE activities hence the inclusion in this study.

\section{Methodology}

This study adopted the quantitative research approach from the positivists' onthology and epistemic approach or paradigm. Specifically a 
correlational design was adopted. The reason that necessitated the use of this design was that the study sought to establish relationship and effect of work life balance and job satisfaction among staff of CoDE. The total population for the study was 250 employees comprising 82 junior staff, 31 senior members and 137 senior staff. However, the accessible population was 242 due to the fact that eight staff were on study leave as at the time the study was carried out.

A sample of 140 respondents was drawn across the four spectrums of staff representing $58 \%$ of the 242 staff at CoDE for the study. This was far higher and would give better representation based on the assertion held by Amedahe and Gyimah (2005) that a sample of 10 percent or above of a population is a good representation. The simple random sampling method was adopted to ensure that every respondent had equal chance of been selected for the study. The research instrument which was questionnaire had items that were measured on a scale of 1 to 4 with 1 representing strongly disagreement while 4 represented strong agreement. Data for the study was collected on work and life balance and job satisfaction. In all 115 completed questionnaire were received representing a response rate of 82.1 percent. The reason for this high turnout rate was the researchers' consistent reminder and follow up to respondents.

\section{Main Body (Results and Discussion)}

Presentation in this section is based on the two objectives of the study. The first research question of the study was: What is the level work life balance and job satisfaction among staff of CoDE? This research question was answered by firstly looking at respondents' perception of the items making up the variable work and life balance and also determines the level of relevance to employees. The result to this effect can be seen from Table 1. It is evident from the table that the negative effect

Table 5: Respondents Perception of Items of Work and Life Balance at CODE

Std.

\begin{tabular}{|c|c|c|c|c|c|}
\hline & $\mathrm{N}$ & Minimum & Maximum & Mean & Deviation \\
\hline My job is affecting my social life negatively & 115 & 1.00 & 4.00 & 2.7652 & .99411 \\
\hline I live with my family & 115 & 1.00 & 4.00 & 2.5652 & 1.14808 \\
\hline My job is affecting my personal life negatively & 115 & 1.00 & 4.00 & 2.5304 & .92073 \\
\hline My job is affecting my marital life negatively & 115 & 1.00 & 4.00 & 2.4522 & .97552 \\
\hline $\begin{array}{l}\text { CODE job meets my social needs since it helps } \\
\text { me meet several people }\end{array}$ & 115 & 1.00 & 4.00 & 2.2435 & .95137 \\
\hline I spend sufficient time with my spouse and family & 115 & 1.00 & 4.00 & 2.0522 & 1.01604 \\
\hline \multirow[t]{2}{*}{ I make time to pursue my interest and hobbies } & 115 & 1.00 & 4.00 & 1.8696 & .88379 \\
\hline & & 2.4 & & & \\
\hline
\end{tabular}

Source: Field Data, 2014 
Scale: Below 1.9 = Very Low, 2:0 $-2.4=$ Low, $2.5-2.9=$ High, 3.0 and above $=$ Very High

of CoDE activities on respondents' social life $(\mathrm{M}=2.8)$, personal life $(\mathrm{M}=2.5)$ and marital life $(\mathrm{M}=2.5)$ was perceived high. All the remaining four items were rated very low. That means that the CoDE activities or job schedules takes the greater part of staff's time and they could hardly make time to pursue their social, marital and personal life. The overall mean of $(M=2.4)$ shows that work life balance as a variable was perceived low among staff of CoDE. This has serious effect on work output and can seriously stress up employees as concluded by the findings of Nicole (2003) that employees with low work and life balance experienced high level of stress, absenteeism with its consequent effect on productivity.

The second aspect of research question one was on respondents' perception of job satisfaction as a variable. Result for respondents' perception of elements of job satisfaction can be seen from Table 2. The physical environments $(\mathrm{M}=2.9)$, ability to use ones initiative on the job $(\mathrm{M}=2.8)$, and amount of variety in CoDE activities $(M=2.7)$ were perceived to be high. That means that CoDE staff were satisfied with the physical environments and the personal initiatives they brought to bear on the job. This can lead to high employee motivation as indicated in the findings of Mullins (2010) that job roles with variety of tasks which also requires employees initiatives result in interesting and challenging job which are intrinsic form of motivation.

That notwithstanding, respondents were not satisfied with the risk associated with the CoDE activities on the whole $(\mathrm{M}=2.04)$ and the level of risk and job security for the week-end job $(\mathrm{M}=1.97)$ in particular. That means that CoDE weekends activity/job was perceived by the respondent to be highly risky and respondents were not satisfied with the existing security measures for the high risk involved. This can lead to fear and anxiety with its resultant effect on performance. This finding collaborate with that of Olorunjuwon, (2008) that high risky jobs posses fear and threat to employees and their performance. 
Table 2: Respondents Perception of Items of Job satisfaction at CoDE

\begin{tabular}{|c|c|c|c|c|c|}
\hline & $\mathrm{N}$ & $\begin{array}{ll}\text { Mini } & \text { M } \\
\text { mum } & \text { ur } \\
\end{array}$ & $\begin{array}{l}\text { Maxim } \\
\text { um }\end{array}$ & Mean & $\begin{array}{l}\text { Std. } \\
\text { Deviation }\end{array}$ \\
\hline $\begin{array}{l}\text { Am happy with the physical environment and } \\
\text { working conditions in CODE }\end{array}$ & 115 & 1.00 & 4.00 & 2.9304 & .76916 \\
\hline $\begin{array}{l}\text { There is opportunity to use my initiative and abilities on } \\
\text { my job }\end{array}$ & 115 & 1.00 & 4.00 & 2.7913 & .77794 \\
\hline Am satisfied with the amount of variety in my work & 115 & 1.00 & 4.00 & 2.7217 & .73207 \\
\hline Am happy with the amount of responsibility given to me & 115 & 1.00 & 4.00 & 2.7130 & .69793 \\
\hline $\begin{array}{l}\text { Am satisfied with hours of work (week days and } \\
\text { week-ends) }\end{array}$ & 115 & 1.00 & 4.00 & 2.5130 & .82041 \\
\hline My job at CODE is what I was trained to do & 115 & 1.00 & 4.00 & 2.4783 & .90173 \\
\hline Am satisfied with the current preparations for the week-end job & 115 & 1.00 & 4.00 & 2.4696 & .75303 \\
\hline Am happy with attention paid to suggestions I make at work & 115 & 1.00 & 4.00 & 2.2174 & .85617 \\
\hline Am satisfied with the risk associated with the CODE job & 115 & 1.00 & 4.00 & 2.0348 & .85768 \\
\hline $\begin{array}{l}\text { Am satisfied with the level of risk and job security for the week- } \\
\text { end job. }\end{array}$ & 115 & 1.00 & 4.00 & 1.9739 & .83204 \\
\hline Valid N (listwise) & 115 & & & & \\
\hline
\end{tabular}

Source: Field Data, 2014

Scale: Below $1.9=$ Very Low, 2:0 $-2.4=$ Low, $2.5-2.9=$ High, 3.0 and above $=$ Very High

\section{Research Question two: What relationship and effect exist between work life conflicts on employee job satisfaction at CoDE, UCC?}

Research question two was on relationship and effects of work life conflict and job satisfaction among staff of CoDE? To answer this research question, Pearson correlation matrix and multiple standard linear regressions were run and the result can be seen from tables 3 and 4 respectively.

Table 3: Correlations Matrix on relationship between work life balance/conflict and job satisfaction at CoDE, UCC

\begin{tabular}{|c|c|c|c|c|c|}
\hline Factor & & Mean & Std deviation & Job satisfaction & Sig. \\
\hline $\begin{array}{l}\text { Work } \\
\text { Conflict }\end{array}$ & Life & 2.4522 & .97552 & -.344 & 0.000 \\
\hline
\end{tabular}

\section{$\mathrm{N}=115$}

The correlation matrix (Table 3) indicates that there was moderate, negative and significant relationship between work life conflict and job satisfaction $(r=-.344, p<0.000)$. The explanation for this result is that the more staff experience more work and life conflict (that is unable to perform the social and economic role due to role incompatibility) the lower their job satisfaction. Additionally, the relation observed between work life conflict and job satisfaction was significant at $0.05\left(\mathrm{P}=0.000^{*}\right)$. 
Table 4: effect of work life conflict on employees' job satisfaction among CoDE staff

\begin{tabular}{|c|c|c|c|c|c|c|c|c|c|}
\hline \multirow[t]{2}{*}{ Model } & \multicolumn{2}{|c|}{$\begin{array}{l}\text { Unstandardize } \\
\text { d Coefficients }\end{array}$} & \multirow{2}{*}{$\begin{array}{c}\text { Standar } \\
\text { dized } \\
\text { Coeffic } \\
\text { ients } \\
\text { Beta }\end{array}$} & \multirow[t]{2}{*}{$\mathrm{t}$} & \multirow[t]{2}{*}{ Sig. } & \multicolumn{2}{|c|}{$\begin{array}{l}\text { Collinearity } \\
\text { Statistics }\end{array}$} & \multirow[t]{2}{*}{$\begin{array}{c}\mathrm{R} \\
\text { Square }\end{array}$} & \multirow{2}{*}{$\begin{array}{l}\text { Adjuste } \\
\text { d } \\
\text { Square }\end{array}$} \\
\hline & B & $\begin{array}{c}\text { Std. } \\
\text { Error }\end{array}$ & & & & Tolerance & VIF & & \\
\hline (Constant) & $\begin{array}{l}2.8 \\
80\end{array}$ & .109 & & 26.395 & .000 & & & .118 & .111 \\
\hline $\begin{array}{l}1 \text { work and life } \\
\text { conflict }\end{array}$ & $\begin{array}{c}- \\
.16 \\
1\end{array}$ & .041 & -.344 & -3.897 & .000 & 1.000 & 1.000 & & \\
\hline
\end{tabular}

a. Dependent Variable: Job Satisfaction

In Table 4, work life conflict was entered as independent variable and it had a statistical significant relationship with job satisfaction. As Table 4 shows, work life conflict $(\beta=-0.344(0.000), \mathrm{p}<0.01)$ was able to predict job satisfactions. It is however significant to observe that the unique proportional contribution of work life conflict to the dependent variable which was job satisfaction was 0.118 with an adjusted $\mathrm{R}^{2}$ of 0.111 . This means that work life conflict is able to contribute, predict or explain about 12 percent of the variance in job satisfaction. It therefore means that besides work life conflict, other variables not yet in the model have a chance of contributing or predicting about 88 percent to the job satisfaction. This means that to ensure job satisfaction at CoDE, the level work life conflict among staff should be reduced.

\section{Conclusion and recommendation}

It can be concluded for that work life balance among staff of CoDE was low such that the social life, personal life and marital life of staff conflicted with work demands. Additionally, the level of job satisfaction among CoDE staff was low. It can also be concluded that there was a negative moderate but significant relationship between work life conflict and job satisfaction among staff of CoDE. Also work life conflict explains about $12 \%$ in the variance in job satisfaction.

The above conclusions indicate a need for certain action to take place by management (advisory committee). It is therefore recommended that the management of CoDE should:

1. Introduce leave schedule or a day off for staff in order to have sufficient time to attend to their personal, marital and social life and rest. This is because staff work for 56 hours a week and that contravenes the labour law of Ghana and the International Labour Organisation (ILO) convention which Ghana is a signatory. 
2. Cover the week-end travelling with an insurance package to take care of high risk involved

3. Introduce job rotation and solicit more views of staff as well as the to ensure job satisfaction and work life balance.

4. Introduced inter-unit assignment and recreational activities for staff on public holidays.

\section{Suggestion for Future studies}

1. Other studies could tackle the effect of job related factors on job satisfaction among distance education workers in terms of academics and non academics.

2. The variable of the study explained o 12 percent of the variance in job satisfaction of staff on the distance programme. Thus, another study could be conducted to determine what other factors apart from job related factors influence teaching and non teaching staff of distance education institutions in Ghana.

3. A comparative study with staff in the main regular stream and that of the distance mode is also another area for possible further studies.

4. Another possible area for further study is a collaborative study between CoDE/UCC and any other Universities.

\section{References:}

1. Amedahe, F. K., \& Gyimah, E. A. (2005). Introduction to educational research. Accra-North: Mercury Press.

2. Cinamon, R. \& Rich, Y., (2010). Work family relations: Antecedents and outcomes. Journal of Career Assessment, 18, 59-70.

3. Ghana Labour Act (2003). Act 651. Ghana: Accra

4. Jennings, J. \& McDougald, M. (2007). Work-family interface experiences and coping strategies: Implications for entrepreneurship research and practice. Academy of Management Review, 32 (3), 747760.

5. Katz, D., \& Kahn, R.L. (1978). The social psychology organization, ( $2^{\text {nd }}$ ed.).New York: Wiley

6. Kang, D., Rice, M., Park, N. Turner-Henson, A. \& Downs, C. (2010). Stress and inflammation: 94. A biobehavioural approach for nursing research. Western Journal of Nursing Research, 32 (6), 730-760.

7. Mullins, L. J. (2010). Management \& Organisation al Behaviour $\left(9^{\text {th }}\right.$ ed.). Harlow, England: Pearson Education Limited.

8. Nicole, E. A. (2003). "The difficulty of leaving work inside the prison walls: An explanatory analysis of female correlational officer identity". Presented at the annual meeting of the American Society of Criminology, Chicago, IL. 
9. Olorunjuwon, S. M. (2008). Using motivational strategy as panacea for employee retention and turnover in selected public and private sector organisations in the Eastern Cape province of South Africa. Master of Commerce Dissertation, University of Fort Hare, South Africa.

10. Porter, S., \& Ayman, R. (2010). Work flexibility as a mediator of the relationship between work- family Conflict and intention to quit. Journal of Management \& Organization, 16, 411- 424.

11. Powell, G. N., \& Greenhaus, J. H. (2010). Sex, gender, and the worktofamily interface: Exploring negative and positive interdependencies. Academy of Management Journal, 53, 513-534.

12. Rabia, A., Sadaf S., Mahwish A., \& Shama S. (2011). Work-Family Conflicts: Relationship between Work-Life Conflict and Employee Retention - A Comparative Study of Public and Private Sector Employees. Interdisciplinary Journal of Research in Business, 1, 2-4.

13. Riggio, R. E. (2003). Introduction to industrial/organisational psychology. New Jersey: Pearson Education. Segbenya, M., AnnanPrah, E.C., Enu-

14. Kwesi, F., \& Koomson, F. (2013). Employee retention and attainment of organisational goals in Ghana Commercial Bank, Kumasi. Journal of Business and Enterprise Development 4 (1), 2026500

15. Shobitha, P. \& Sudarsan, N. (2014). Work Life Balance: A Conceptual Review. International Journal of Advances in Management and Economics, 12 (3) 2278-3369

16. Wan, H. L. (2007). Human capital development policies: Enhancing employees' satisfaction. Journal of European Industrial Training, 31(4), 297-319. 